\title{
Finno-Ugric words in the Russian dialects of Yakutia
}

\author{
Larisa Samsonova*, Tatiana Nikaeva, and Marfa Tarabukina
}

NEFU, Faculty of Philology, 677000, 42 Kulakovsky str., Yakutsk, Russia

\begin{abstract}
This article analyzes the lexical Finno-Ugric borrowings that appeared in the speech of the Slavs and the aboriginal population of Yakutia with the arrival of the Russians to the northeast Siberia in the $17^{\text {th }}$ century. More than three centuries ago, the Russians, who came from the northern provinces of Russia, introduced the essential vocabulary necessary for the daily life of the people of that time into the active vocabulary of the northern region's population. Most of the words from the Finno-Ugric languages denoted new concepts and did not have synonyms in Russian, for example, viska, edoma, laida, etc. This research investigates and illustrates the most significant thematic groups of the borrowed words, gives lexical-semantic characteristics of the analyzed notions, and determines the basic word-building patterns. This article presents the results of a linguistic experiment on the interpretation of words, which was conducted in 2021 among the students of Ammosov North-Eastern Federal University to determine the relevance of the Finno-Ugric layer of vocabulary in the modern communicative situation of the Sakha Republic (Yakutia). The authors of the article conclude that the studied lexical borrowings, which became widespread on the territory of the republic several centuries ago, underwent some changes, became the basis for the formation of new words, became part of not only the modern Russian literary language, but also other languages of the republic, where they are part of the active vocabulary.
\end{abstract}

\section{Introduction}

The arrival of the Russians from the northern provinces of Russia to the northeast Siberia in the $17^{\text {th }}$ century influenced the language of the indigenous population of this region and introduced, among other, the Finno-Ugric linguistic borrowings, that can be found in the speech of the residents of the Sakha Republic (Yakutia) in the $21^{\text {st }}$ century. The Russians from the northern Russian regions of Europe quickly populated the entire northeast Asia, discovered such rivers as the Lena, the Anabar, the Vilyui, the Olenyok, the Kolyma, the Yana, the Indigirka, and the Alazeya. From late $16^{\text {th }}$ century to early $18^{\text {th }}$ century Siberia was mostly populated by the Russians from the northern provinces of Russia.

In the first half of the $17^{\text {th }}$ century, the Russians who lived between Novgorod and Vyatka arrived in the Lena region. Their language had been formed for several centuries on the basis of the Great Russian dialects (Novgorod, Arkhangelsk, Ustyuzhna, Vologda, etc.).

Having arrived to the northeast of the country, the new residents started their life with the linguistic background of the Russian dialects of northern Europe in the $16^{\text {th }}-18^{\text {th }}$ centuries. That is why, the speech of the Russians in Yakutia had a lot of borrowings from the Finno-Ugric languages, brought from the northern motherland.

In the new conditions, these words appeared to be essential and useful as the Russians in the northeast Asia found themselves in the living conditions similar to those in the north of the European part of Russia. The words of the Finno-Ugric languages came into common use of both the Russian population and the indigenous population of Yakutia.

\section{Materials and methods}

The practical material for the article includes the documentation (handwritten and dictaphone) of oral spoken speech of the old-timers. It was documented by the students engaged in the expeditions to collect dialect words, organized by the Department of Russian Language and General Linguistics of Yakutsk State University. At different times, these expeditions were led by M.F. Druzhinina and N.G. Samsonov. The expeditions were organized in various districts of the republic in 1959-1986. These expeditions resulted in the "Dictionary of Russian old-time dialects on the territory of Yakutia" of 4 volumes by M.F. Druzhinina, which was republished in Yakutsk thrice in different years.

At present, the Russian old-time dialects are actively researched by Berdnikova T.A. [1], Pavlova I.P. [1,2,3], Zhondorova G.E. [1,4], Gorbunova Ya.Ya. [1,3], and Semyonova N.M.[5]. There also is fragmentary information about the language, preserved by the members of different Siberia-exploring expeditions (V.M. Zenzinov. V.G. Bogoraz, later - O.I. Gordeyeva,

\footnotetext{
Corresponding author: samsonova_flf@mail.ru
} 
S.I. Olgovich, A.I. Fyodorov, and others). But a detailed analysis of the Finno-Ugric elements in the Russian dialects has not yet been done. This explains the relevance of our study.

The main purpose of the work is to identify and analyze the Finno-Ugric words in the Russian dialects of Yakutia, as well as to determine their relevance.

The research includes the following tasks: 1) to identify the Finno-Ugric vocabulary and organize it into thematic groups; 2) to define the meaning and etymology of the Finno-Ugric borrowings; 3) to determine the relevance of the Finno-Ugric vocabulary borrowed almost three centuries ago in the modern communicative situation of the Sakha Republic (Yakutia).

The Finno-Ugric elements in the speech of modern youth in the north-east of Siberia have not been studied systematically yet, which gave us the idea of investigating this issue.

\section{Results and Discussion}

After analyzing the handwritten documentation and dictaphone records of dialectological expeditions and dictionary entries (dictionary by M.F. Druzhinina, a number of etymological dictionaries), we have identified the following thematic groups of the Finno-Ugric vocabulary in the Russian dialects of the Lena region: 1) words denoting geographical objects, expressions and terrain; 2) terminology related to fishing; 3) words related to hunting and reindeer husbandry; 4) words related to the names of clothes and boots; 5) words denoting various everyday concepts. Let's take a look at each of these groups.

Let's bring several examples from each thematic group.

\section{Words denoting geographical objects, expressions and terrain}

This is the largest and most widely used group of the Finno-Ugric vocabulary. This is explained by the fact that the basins of such northern rivers as the Yana, the Indigirka, the Kolyma, etc., primarily their lower reaches, are rich in marshland, dissected with bays, rivers, and streams.

This group includes the following words:

В 'ИСКА VISKA - "Feminine gender. A small river. - He traded with the Lamuts behind Panteleikha, up the viska and in another place. 2. A channel joining a lake with a river - Pokhodsk viska starts from Nerpiche Lake and flows into the Kolyma" [6].

Researchers derive the Russian viska from a Komi word viska-ti "a lake from which a river flows into the other lake" [2].

К`АЛТУС KALTUS - "Masculine gender. Squashy ground, wet meadow; tussock bog. - Cloudberry, cranberry on the kaltus" [6].

This word is considered to be a borrowing from the Samoyed kalz "oozy place" [7].
КУЛ ИГА KULIGA - "Feminine gender. 1. Glade; forest glade, cleared for ploughland. - Go to the forest behind the kuliga. 2. Narrow and deep bay" [11].

According to the Finnish researcher J. Kalima, this word is borrowed from the Finnish language kyla "village" [12].

КУРЬ Я KURIYA- "Feminine gender. Crease, deadend creek, lost in the swamps; river bay. - There was a fishy kuriya here" [11].

This word is usually compared with the Komi kurja "bay". They also relate it with the Finnish kury "trench" [12].

Kuriya is one of the early Finno-Ugric borrowings, which is proven by its use in the monuments of the old Russian literature.

ЛАЙДА LAIDA - "Feminine gender. Bay lake; riverside shallow, uncovered by the low tide; shore shallow between the high tide and the low tide; overflow lake. - Laida is a shallow lake, there are a lot geese there" [6].

The researchers explain the etymology of the word laida in the Russian dialects in different ways. Thus, J. Kalima believes that it was borrowed from the Vepsian laid "middle of the lake, wide water area". However, for the dialects of Yakutia, the meaning of the word laida is closer to the meaning of the Finnish laito (genitive case laidon "shallow" and the Estonian laid "small island, shallow" [7].

ЛЫВА - LYVA "Feminine gender. Puddle. - Keeps walking in the lyvas barefoot [6].

According to J. Kalime, this word is borrowed from the Finnish and Karelian liiva "ooze, sludge" [7].

ШУГ`А SHUGA - "Feminine gender. Slush ice before the freeze-up or the ice drift. - First goes the ice, then there goes shuga [6].

According to N. Kalima, this word derived from the Finnish sohja, sohjo "icy hash" [7]. Another researcher, M.P. Veske, relates shuga with the Estonian soga "packed ice" [9].

\section{Terminology related to fishing}

This group includes the following words:

К ИБАС KIBAS - "Masculine gender. Plummet of a seine, covered with birchbark. - Plummet of a seine, a net is kibas, it is covered with birchbark. It's made of stone" [6].

The use of the word kibas (instead of the common plummet) in the Russian dialects of Yakutia is explained by its distinctive meaning: it is a special kind of plummet, in particular, a small weight, covered with birchbark and submerged in water.

The researched word goes back to the Finno-Ugric languages: Olonets kives, Finnish kives "plummet on a net" [7].

К ИБАСНЫЙ КІВАSNY - "Adjective from kibas and kibasochek - diminutive-hypocoristic of kibas" [6].

MАKCA MAKSA - "Feminine gender. Burbot liver. - Burbot liver, maksa is very good for frying" [6].

The word is borrowed from the Finno-Ugric languages: the Estonian maks, the Finnish maksa "liver" [7]. 
М ОРДА MORDA - Feminine gender. Weaved fishing gear, fish trap. - Morda is a fish trap, it is weaved" [6].

J. Kalima relates this word with the following Finnic languages: the Finnish merta "fish trap", the Estonian mord, the Livonian morda, the Karelian merda, the Vepsian merd [7].

МОРД УШКА MORDUSHKA - "Feminine gender. Small morda. - We were fishing with mordushka nearby" [6].

MOKC'УН MOKSUN - "Masculine gender. Whitefish. - Moksun is a whitefish, thinner than chir" [6].

There are many points of view regarding the analyzed word. However, according to A.S. Gerd, a well-known expert in ichthyological terminology, muksun is Finno-Ugric: "the word muksun was originally borrowed by the Russians on the $\mathrm{Ob}$, apparently, from the neighboring Khanty-Mansi dialects. From here, it, first of all, came to the Pechora, and through the fish traders, the Russians and the Komi, from Pechora and the lower reaches of the $\mathrm{Ob}$, it got into the texts of business documents, executed in the North, in the $17^{\text {th }}$ century": "Six hundred salted muksuns, two loads of yukola" (Acts of Yakutsk Voivod House (1641); "And plenty of different fish ...muksun" (information book, describing the towns of Siberia, $17^{\text {th }}$ century) [10].

ТАЙМ'ЕН TAIMEN - "Masculine gender. Salmon trout. - I have one taimen, I'll give you" [6].

The word taimen is borrowed from the Finno-Ugric languages: the Finnish taimen, genitive case taimenen "trout", the Estonian taim, genitive case taime [7].

ХАЙРУЗ KНAIRUZ - "Masculine gender. Grayling. - "In our river, we have khairuz, nelma, burbot" [6].

This word is of Finno-Ugric origin: the Vepsian harduz, harjus, the Karelian harjus, the Finnish harju, harjus [7].

ХАЙРУЗОК КНАIRUZОК - "Masculine gender. Diminutive of khairuz. There are seven khairuzoks on every rift, every khairuzok is seven years old" (Riddle) [6].

ЧИР CHIR - "Masculine gender. Game fish of salmons. - Chir is good, fatty, we make yukola from it" [6].

This word is borrowed from the Komi language $t$ 'sir "a kind of salmon" [7].

‘ЮКЛА YUKLA (yukola, yukula) - "Feminine gender. Yukola. From chir, you can make a fish pie or yukla" [6].

As M. Fasmer suggests, the word yukola originated from the Komi $j u$ "river" and a word close to the Finnish kala "fish" [7].

This word was documented in the business documents of Yakutia of the $17^{\text {th }}$ century: "Six hundred salted muksuns, two loads of yukola" [10].

3. Words related to hunting and reindeer husbandry.

This group includes the following words:
В`АЖЕНКА, В`АЖЕНЬКА VAZHENKA "Feminine gender. Female reindeer. - Female reindeer is vazhenka" [6].

The word is borrowed from the Sami vadz "young female reindeer" [7]. Suffix -enk- came from the Russian language.

КУЛЁМА KULYOMА - "Feminine gender. Large bear trap. - Kulyoma is for a bear" [6].

The word is borrowed by the Russian dialects from the Komi language, where kulem means a trap, or a net [7].

In the Russian dialects of Yakutia, there is also a word kulyomnik, meaning a trap: "When a wolverine comes, it destroys all kulyomnik" [6].

ЧИРКААН CHIRКАN (cherkan) - "Masculine gender. Ermine trap. - We catch ermines with chirkan" [6].

The word is usually related with the Khanty sorkan, t'argan "a trap" [7].

Through the Russian dialects, the word chirkan penetrated the Yakut language: charkan.

4. Words related to the names of clothes and boots This group includes the following words:

K'AMAC KAMAS and K'AMYC KAMUS "Masculine gender. 1. Skin from the ungulates' lower thigh, used for making boots, mittens, etc. - We process kamus ourselves, and then make boots. 2. Boots from reindeer legs. - We wear embroidered kamus" [6].

This word is documented in the written records of the $17^{\text {th }}$ century of the European north and Yakutia as kamas, kames, kamus, kamys, in particular, in the Acts of the Voivode House of the years 1639 - 1647: "Twenty wapiti kamus" (1640); "Twenty moose kamus five axes" (1644); [10].

КАМ АСИКИ КАМАSIКІ - plural, diminutive of kamas (in its meaning 2)» [6].

К`АМУСНОЙ КАMUSNOY - Adjective from kamus. - I have kamus, I will make the kamus boots myself" [1].

КАМ АСОВЫЙ КАMASOVY, КАМ'УСОВЫЙ KAMUSOVY- "Adjective from kamas, kamus. - Men made kamus mittens for hunting" [6].

The adjective kamusnoy, kamusny is documented in in the written records of the $17^{\text {th }}$ century, in particular, in the Acts of Yakutsk Voivode House: "Posnichko and his friends brought Russian saddle bags ... and their saddle bag was Yakut, from kamys, with reindeer boots in it" (1641) [10].

Р ОВДУГА ROVDUGA - "Feminine gender. Home-processed chamois. - Everything was made from rovduga: shirts, gloves" [6].

The word goes back to the Sami word roavggo "sleigh robe from skins" [7].

\section{Words denoting various everyday concepts}

This group includes the names of food, household utensils and other colloquial vocabulary.

К`АРБАЗ KARBAZ and K`AРБAC KARBAS "Masculine gender. 1. Karbaz, high-sided boat made from half-timber for transporting cargos. - Karbaz with goods has arrived. 2. Karbas half-timber [6]. 
The word derives from the Finnic languages: the Vepsian karbaz, the Finnish karbas "a boat difficult to carry" [7].

Through the Russian dialects, this Finno-Ugric word penetrated the Yakut language: kharbas and was used in Yakutia until the 1917 Revolution and in the first years of the Soviet era, when cargos were shipped on these boats down the Lena River.

ПУРГА PURGA - "Feminine gender. Blizzard, snowstorm. - There's purga again, the roads are covered with snow" [6].

ПУРГА гнев-гневная PURGA rageful - "Very strong. - We stay in yurta during a rageful purga [6].

ПУРГА малая PURGA small - 'Snowstorm. There has been a small purga, not very strong" [6].

ПУРГА тёмная PURGA dark - "Strong purga, purga with snow dust". - A dark purga is very strong, you can't see anyone, there's thick dust all around and snow" [6].

This word goes back to the Finnic languages: the Karelian purgu "a storm with a snow tornado", the Vepsian purg, the Finnish purku "snow storm" [7].

T'YE3 TUEZ, T'YEC TUES - "Masculine gender. Birchbark basket with firm cover. - Tuez is from birchbark, it's good for all" [6].

TУEC'OK TUESOK - "masculine gender. Diminutive of tues. - Could you bring me a tuesok of milk?" [6].

TУЕС`ОЧЕК TUESOCHEK - "Masculine gender. Diminutive of tues - Cold water lasts long in tuesochek" [6].

Tuez, tues in the above meaning is well-known not only in the Russian dialects of Yakutia, but in many dialects of the European North and the Ural.

It is believed to have entered the Russian dialects from the Komi language, where tujes means a birchbark box [12]. Compare with the Udmurt tujis "a birchbark box with wooden cover" [7]; the Votyak tujis. It is for the first time fixed in the dictionary as tuez in1847 [12].

Through the Russian language, the word TУEC TUES came to the Yakut language: tuyas "a birchbark vessel with wooden cover". It should be noted that in the times of E.K. Pekarsky, the author of the Yakut dictionary, the Yakuts distinguished between a Yakut and a Russian tues: Sakha tuyasa (Yakut tues) - it is large, flat, made from several pieces of birchbark, a bast basket with a removable cover; nutcha tuyasa (Russian tues) - a small round bast basket from one piece of birch, also with a removable cover [13].

It is interesting to note that the Yakut word tuyas has equivalents in other Turkic languages: the Kyrgyz toyaz, Baraba dialect tuyus [13].

Ч АГА CHAGA - "Feminine gender. Fungus. - Tea was made from chaga during the war, and we drank tea with milk" [6].

According to M. Fasmer, this word goes back to the Komi tsak "mushroom, sponge" [7].

ШАНЬГА SHANGA - "Feminine gender. A sweet bun, flatbread, crisp bread. - We baked gassy shangas, if the flour was good" [11].

The word is borrowed from the Komi sanga [9].
ШАНЕЖКА SHANEZHKA, ШАНЕЧКА SHANECHKA - "Diminutive of shanga. - We baked shanezhkas on holidays" [6].

Most words from the Finno-Ugric languages in the $17^{\text {th }}$ century introduced new concepts and didn't have synonyms in the Russian language, for example, viska, edoma, laida, kuriya, kamus, kulyoma, cherkan, and others.

Since the morphological systems of the Russian language and the Finno-Ugric languages are different and there is no category of gender in the Finno-Ugric languages, after being borrowed, these words began to comply with the grammatical system of the Russian dialects. They entered the Russian morphological system and functioned there as the words of the feminine or masculine gender, the first or second declension of nouns. Thus, the words ending in $-\mathrm{a}$ were interpreted as those of feminine gender, similar to the Russian words ending in -a, and had a type 1 declension: laida - laidy laide - laidu, etc., morda, lyva, tundra, viska, kuliga, kuriya. The words ending with a consonant were perceived as the nouns of masculine gender and had a type 2 declension: kaltus - kaltusa - kaltusu - kaltus, etc., kibas, moksun, khairuz, chir, cherkan.

Some words have undergone a phonetic transformation: a substitution by voicelessness/sonance, for example, tuez - tues and further tuesok; khariuz kharius, and others (in the Russian language, voiced consonants at the end of the words are devocalized); a substitution by hardness-softness: taimen - taimen'; epenthesis: yukla - yukola, metathesis: khairuz kharius. Vowels in the words moksun - muksun, kamas kamus, and others, changed and fixed in the new form.

The contact between the languages and the adaptation to the new grammar system can be seen at the level of word formation. Firstly, it can be a formation of new lexemes from the Finno-Ugric stems, mostly by a terminational manner of derivation, for example, the formation of the diminutive-hypocoristic forms of the nouns kulyoma - kulyomnik, karbaz - karbazik, kibas kibasok, lyva - lyvochka, khairuz - khairuzok, tuez tuezok, tuezochek. Secondly, we witness the examples of the formation of new parts of speech, in particular, adjectives, for example, kamas (kamus) - kamasovy, kamusny, kibas - kibasny, muksun - muksunnoy. Thus, we note that linguistic adaptadness of the borrowed Finno-Ugric words in the Russian dialects of Yakutia is a complicated process that touches upon the basic language levels.

\section{Linguistic experiment}

To determine the activity and relevance of the listed lexical units in the modern communicative space of the Sakha Republic (Yakutia), a linguistic experiment was conducted in 2021 among the students of Ammosov NEFU. It embraced 200 people total: aged 18 to 25 $72 \%, 26$ to $35-28 \%$. The questionnaire was prepared on the Google forms platform and sent to the respondents through an active link to the messengers. The respondents were asked to correlate the previously 
formulated lexical meaning with the words borrowed from the Finno-Ugric languages and found in the Russian dialects of northeastern Siberia as early as in the $17^{\text {th }}$ century.

The analysis of the experiment's results has shown that some of the studied words turned out to be unfamiliar to the modern youth. Most of the respondents answered "I don't know" or gave a wrong definition of the following words: kaltus, chirkan $(63 \%$ of the respondents don't know or give a wrong definition of this word); kuriya, kulyoma, kuliga (62\%), laida (69\%), kibas (64\%), viska, karbaz, lyva (60\%), kanbula (53\%) and others. This suggests that the words denoting geographical objects, terrain and the Finno-Ugric terminology related to fishing have gone out of active use.

It was less difficult to define the words most of which denote different everyday concepts: tues/tuesok (birchbark dish), shanezhka (sweet bun), moksun/muksun (fish), chaga (mushroom, medicine), maksa (burbot liver), pyzhik (young reindeer of its fur); from the geographical objects and concepts, a familiar one is shuga (slush ice); from the terminology related to fishing, many know the word morda /mordushka (fishing gear). The semantics of the above words is familiar to $50 \%-60 \%$ of the experiment's participants.

The active vocabulary of the modern youth includes the following Finno-Ugric borrowings: chum (dwelling); chir, kharius, taimen, yukola (fish), tundra (natural zone), purga (blizzard), kamus (reindeer skin), and others. 80 to $95 \%$ of the respondents gave a correct definition of these words.

\section{Conclusion}

From the above, it is clear that the words of Finno-Ugric origin that we have reviewed are part of a large number of thematic groups and represent a certain layer of borrowed vocabulary in the Russian dialects of Yakutia. Many of the analyzed words penetrated the Russian literary language and the languages of the peoples of Yakutia through the dialects. The Finno-Ugric words adapted to the grammatical structure of the Russian language and got a new phonetics. It is important to note that one part of the words is not only not used in modern communication, but is completely unfamiliar to the residents of the republic. The other part of the words has changed or become the basis for the formation of new lexemes that are in demand today. There are also borrowed Finno-Ugric words that have survived unchanged and were adopted by the Russian and other languages common in the north-east of Russia.

\section{References}

1. T.A. Berdnikova, Ya.Ya. Gorbunova, G.E. Zhondorova, I.P. Pavlova The Image of a Russian Person in the Northern Worldview: Based on a Study of Russian Dialects Used by The Old Timers of Yakutia, Modern Journal of Language Teaching Methods. 7(11), p. 249-260, (2017).
2. I.P. Pavlova Hunt vocabulary in the Russian subdialects of Yakutian old-timers Opcion, 34 (85), 1010-1028, (2018)

3. Ya.Ya. Gorbunova, I.P. Pavlova, Linguistic and Cultural Features of the Russian old-timers' dialects of Yakutia (based on material of dictionaries of M.F. Druzhinina), Amazonia Investiga, 8(24) (2019).

4. Zhondorova G.E. Semantic space "image of a human" (on the material of the Russian old-time dialects of Yakutia) Bulletin of Herzen Russian State Pedagogical Institute 15, 223-229, (2012)

5. N. M. Semyonova Representation of a concept of "house" in the Russian old-time dialects in Yakutia, Bulletin of Ammosov North-Eastern Federal University 4 (54), 101-108, (2016).

6. M.F. Druzhinina Dictionary of Russian old-time dialects on the territory of Yakutia: of 4 volumes. (Yakutsk, 2007)

7. M. Fasmer Etymological dictionary of the Russian language: of 4 volumes. (SaintPetersburg, 1996).

8. I.I. Sreznevsky Materials for the dictionary of the old Russian language. (Moscow, 1958).

9. M.P. Veske, Slavic-Finnish cultural relations according to the language, Bulletin of the Society of Archaeology, History and Ethnography at Kazan Imperial University. Kazan, 8(1), (1890).

10. Dictionary of the Russian language of the $11^{\text {th }}$ $17^{\text {th }}$ centuries. (Moscow, 1982).

11. Additions to the historical acts, collected and published by the archaeographic commission: [of 12 volumes]. (Saint-Petersburg, 1846-1872).

12. N.M. Shansky, V.V. Ivanov, T.V. Shanskaya, Brief etymological dictionary of the Russian language. (Moscow, 1971).

13. E.K. Pekarsky, Dictionary of the Yakut language. (Moscow, 1959).

14. Dictionary of the contemporary Russian literary language: of 17 volumes. (Moscow. - Leningrad, $1950-1965)$. 